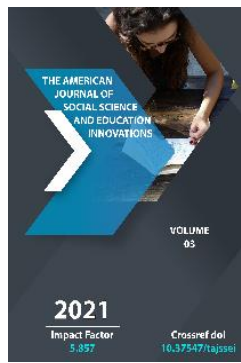

\title{
Listening skills of schoolchildren as an important factor of understanding and contemplation
}

\author{
Abdurahmanov Bahrom Sabitovich \\ Senior Teacher, Namangan State University, Uzbekistan
}

Journal Website:

http://usajournalshub.c

om/index,php/tajssei

Copyright: Original content from this work may be used under the terms of the creative commons attributes 4.0 licence.

\section{ABSTRACT}

Oral speech presupposes the presence of listeners, IE. in its essence, it is intended for interpretation. Oral treatment of people is of great importance to the ability to listen traditionally in different situations. Of course, the ability to listen to the interlocutor without interrupting his speech is great in business relations, and sometimes plays a decisive role: business conversations, negotiations, discussions, disputes. Another point for business communication is very relevant: in the process of communication, General Knowledge, Common Interests, goals and mutual understanding are the starting points of effective speech communication, which form the "speech plan" and "audience plan". When these plans coincide, an ideal situation is created for the perception of oral speech, which is associated with a certain influence on the consciousness and feelings of the audience.

\section{KEYWORDS}

Images, schemes, ideas, concepts and images, concepts, physical and psychological stresses.

\section{INTRODUCTION}

Hearing or listening is the process of thinking about a very complex speech, which is called "passing code through an acoustic code", in which the listener with his ear, with his auricle, 
transfers the thought voiced by another person to the code. understanding the inner speech, the code of thought, the accepted speech, because the intellectual code of each person is individual in the sense of keeping in his memory the phonemic norms of words related to the foundation of images, schemes, ideas, concepts and images, concepts "[1].

Atvater "I'm listening to you ..."[2] in his book he writes about two types of listening reflective.

Without reflux - this is a kind of listening, which does not clearly react to what is heard. At first glance, such listening seems passive, but it requires significant physical and psychological stresses. Listening, which does not reflect in a dialogue, is used in situations where one of the interlocutors is excited, wants to express his attitude to a particular event, wants to discuss painful problems and is difficult to express his thoughts. However, such hearing is not always relevant. Lack of response can be perceived as a sign of compromise. Therefore, in business communication, another type of listening reflex prevails. Its essence is in the expression of reaction to what has been reported. These reactions can be different:

The reaction to assimilation of information: Yes, well, well (along with a little hint of the head);

- Reaction of consent: this is correct, correct, yes, no doubt (a slight gesture of the head);

- Surprise reaction: what you ate! What are you saying! Just think! as usual);

- Angry reaction: you know! That's a lot! (strong head efforts).
Reflexive listening involves the active use of gestures and mimics. This type of listening allows you to regulate the data transfer process among themselves. Detection, the ability to ask back what has been heard, makes reflective listening more effective than reflective listening.

There are several types of reflexive answers: explanation, paraphrasing, reflection of emotions and generalization.

An explanation is an appeal to the speaker for an explanation; it helps to make the message understandable to the listener. To obtain more information or to clarify the meaning of individual words, the listener can use the following formulas:

-Please be sure to clarify this ...,

- Do it again?

-What do you think?

- How do you understand this problem?

Interest in the subject of the message itself, striving to understand the essence of the problem, makes the conversation more effective.

To clarify the information, the listener can use both "open" and "closed" questions. "Open" questions cause the speaker to read or narrow the original message; this type of question is usually preferred. Simple" closed "questions that require" yes "or" no " answers are directed from the speaker to the listener, which sometimes forces the speaker to defend himself.

Parafrazing. In other words, the same idea must be formulated differently. Paraphrasing 
in conversation consists in conveying the speaker's own message, but in the words of the listener.

The purpose of paraphrasing is to formulate the message itself to verify the clarity of the speaker's understanding. Paraphrasing can begin with the following words:

- As I understand you ...;

- In your opinion ...

- As I understand you ... having no demoqdes;

- In other words, in your opinion ...

Thus, repeating the message allows the speaker to listen to and understand it, if it is misunderstood, then he will make appropriate corrections to the message in due time.

Reflection of emotions. The main thing here is that the feelings expressed by the speaker by the audience, his attitude and emotional state are reflected. Although it is not always easy to understand the difference between emotions and the content of messages, it often becomes decisive during a conversation.

To conclude. Summary statements help to connect the fragments of the conversation to the semantic unity, they summarize the main ideas of the speaker and are quite appropriate in long conversations. Interlocutors can spend a lot of time responding to superficial, distracting words, instead of generalizing statements, discussing the content of the problem itself. It is necessary to draw conclusions in problematic situations, as well as in the discussion of disagreements, in the settlement of disputes, in the consideration of claims. Summary statements are made in different ways, but the usual introductory phrases can be as follows:

- At the same time, what you say can mean the following ...;

- Your main ideas, as I understand them ...:,

- $\quad$ To summarize the words you said, then ...

A few rules for effective listening [3]:

1. Do not avoid responsibility for communication; do not forget that at least two people participate in communication: one speaks, the other listens, and in the role of the listener, each of them acts alternately;

2. Be attentive to the speaker, turn away from him, maintain a visual connection with him; make sure that your posture and gestures indicate what you are listening to;

3. Focus your attention on what another person is saying; listening requires a conscious concentration of attention, since the attraction of attention can be shortlived;

4. Try to understand not only the meaning of words, but also the feelings of the interlocutor, do not forget that people convey their thoughts and feelings according to the "coded"-socially accepted norms; listen not only to information, but also to transmitted emotions;

5. Be agreeable to the interlocutor, this creates a favorable atmosphere for communication; the more the speaker feels approval, the more clearly he expresses what he wants to say; any 
negative attitude of the listener causes a defensive reaction, a sense of insecurity and vigilance in communication to come.

In summary, D.We quote the following words of karnegi: quot;... the ability to listen is less common than almost any other good quality." This is a friendly, sympathetic listener that we need when we are in trouble. "And often all this is what a dissatisfied customer, dissatisfied worker or offended friend wants" [4

Asking is an appeal to the speaker; it helps to make the message understandable to the listener. To obtain more information or to clarify the meaning of individual sentences, the listener can use the following formulas

Please clarify this ...:

- * Do it again?

- * What do you think?

- * How do you understand this problem?

Facts itself interested in the topic of the message, striving to study the essence of the problem makes the conversation more effective

To clarify the information, the listener can use both "open" and "closed" questions. "Open" questions cause the speaker to read or narrow the original message; this type of question is usually preferred. Simple" closed "questions that require" yes "or" no " answers are directed from the speaker to the listener, which sometimes forces the speaker to defend himself.

Parafrazing. In other words, the same idea must be formulated differently. Paraphrasing in conversation consists in conveying its message to the speaker, but in the words of the listener

The purpose of paraphrasing is to formulate the message itself to verify the clarity of the speaker's understanding. Paraphrasing can be started with the following words:

- As I understand you ...;

- In your opinion ...

- As I understand you ... having no demoqdes;

- In other words, you think

Thus, repeating the message gives the speaker the opportunity to listen to and understand it, if it is misunderstood, then he will make appropriate corrections to the message in due time.

Reflection of emotions. The main thing here is that the feelings expressed by the speaker by the audience, his attitude and emotional state are reflected. Although it is not always easy to understand the difference between emotions and the content of messages, it often becomes decisive during a conversation.

To conclude. Summary statements help to connect the fragments of the conversation to the semantic unity, they summarize the main ideas of the speaker and are quite appropriate in long conversations. Interlocutors can spend a lot of time responding to superficial, distracting words, instead of generalizing statements, discussing the content of the problem itself. It is necessary to draw conclusions in problematic situations, as well as in the discussion of disagreements, in the settlement of disputes, in the consideration of 
claims. Summary statements are made in different ways, but the usual introductory phrases can be as follows:

At the same time, what you say can mean the following ..:;

At the same time, what you say can mean the following ..:,

What you are saying at the moment may mean the following ..:

A few rules for effective listening [3]:

1. Do not avoid responsibility for communication; do not forget that at least two people participate in communication: one speaks, the other listens, and in the role of the listener, each of them acts alternately;

2. Be attentive to the speaker, turn away from him, maintain a visual connection with him; make sure that your posture and gestures indicate what you are listening to;

3. Focus your attention on what another person is saying; listening requires a conscious concentration of attention, since the attraction of attention can be shortlived;

4. Try to understand not only the meaning of words, but also the feelings of the interlocutor, do not forget that people convey their thoughts and feelings according to the "coded"-socially accepted norms; listen not only to information, but also to transmitted emotions;

5. Be agreeable to the interlocutor, this creates a favorable atmosphere for communication; the more the speaker feels approval, the more clearly he expresses what he wants to say; any negative attitude of the listener causes a defensive reaction, a sense of insecurity and vigilance in communication to come.

In summary, D.We quote the following words of Karnegi: quot;... the ability to listen is less common than almost any other good quality." This is a friendly, sympathetic listener that we need when we are in trouble. "And often all this is the desire of a dissatisfied client, a dissatisfied worker or an offended friend.

\section{REFERENCES}

1. Копылова, В.В. Методика проектной работы на уроках английского языка / В.В. Копылова. - М.: Глобус, 2007. - 96 с.

2. Крапивкина, О.А. О традициях и инновациях в методике преподавания иностранных языков / О.А. Крапивкина, Ю.О Синева // Вестник ИрГТУ. - 2013. №9 9 (80). С. 274-281.

3. Янкина, Н.В. Традиционные подходы и инновационные технологии в обучении студентов неязыковых специальностей иностранным языкам / Н.В. Янкина // Вестник ОГУ. - 2013. - № 2 (151). С. 300305.

4. Gavin Dudeney, Nicky Hocky. How to teach English with technology. - Harlow: Person Educated Limited, 2007. -192 p.

5. Ефремов, О.Ю. Педагогика / О.Ю. Ефремов. - СПб : Питер, 2010. - 352 с.

6. Новые педагогические и информационные технологии в системе образования: учебное пособие для студентов педагогических вузов и системы повышения квалификации педагогических кадров / под редакцией Е. С. Полат. - М. : Издательский центр «Академия», 2001. - 272 с. 47 
7. Чернилевский, А.В. Дидактические технологии в высшей школе / А.В. Чернилевский. - М. : ЮНИТИ-ДАНА, 2002. - 437 C.

8. Rahimjanovna S. M. Teaching ethics to students in technology education //Asian Journal of Multidimensional Research (AJMR). - 2020. - T. 9. - №. 3. - C. 119-122.

9. Inomidinova D. I. Impact of learning foreign languages on children development //Middle European Scientific Bulletin. - 2021. - T. 8.

10. Rahimjanovna S. M. The professional skill and competence of modern educatorpedagogue //European Journal of Research and Reflection in Educational Sciences Vol. - 2019. - T. 7. - №. 12.

11. Madinabonu Abdumannob kizi Yusufjonova. (2021). A Household Tale in Korean Folklore. INTERNATIONAL JOURNAL OF DISCOURSE ON INNOVATION, INTEGRATION AND EDUCATION, 2(2), 259-263. Retrieved from http://www.summusjournals.uz/index.ph p/ijdiie/article/view/631

12. Madinabonu Yusufjonova "Analysis of a Korean Household Fairy Tale" Published in International Journal of Trend in Scientific Research and Development (ijtsrd), ISSN: 2456-6470, Special Issue | International Research Development and Scientific Excellence in Academic Life, March 2021, pp.128-130, URL: https://www.ijtsrd.com/papers/ijtsrd3877 o.pdf

13. ЮСУФЖОНОВА

M. A. K. ХУДОЖЕСТВЕННЫЕ ИСПОЛЬЗУЕМЫЕ В КОРЕЙСКИХ ПОСЛОВИЧНЫХ ИЗРЕЧЕНИЯХ //МОЛОДЕЖЬ И СИСТЕМНАЯ МОДЕРНИЗАЦИЯ СТРАНЫ. - 2017. - С. 5355.
14. ЮСУФЖОНОВА М. А. К. ОСОБЕННОСТИ ПЕРЕВОДА КОРЕЙСКИХ ПОСЛОВИЦ И ПОГОВОРОК //Поколение будущего: взгляд молодых ученых. - 2016. - С. 226230.

15. ЮСУФЖОНОВА М. А. СТИЛЬ АВТОРА И ЛИТЕРАТУРНОГО ПЕРЕВОДА // Молодежь и XXI век-2017. - 2017. - С. 263265.

16. Худайбергенова 3. Н. и др. "TAHGUN HAQIDA AFSONA", "ONDAL”,"VA “QIROL KIM SURO HAQIDA AFSONA" ASARLARIDAGI IBORALARNING LEKSIKSEMANTIK XUSUSIYATLARI //Молодой исследователь: вызовы и перспективы. 2017. - С. 196-199.

17. Madinabonu Yusufjonova "A FAIRY TALE AS A REFLECTION OF THE NATIONAL CULTURE OF THE PEOPLE" ACADEMICIA: An International Multidisciplinary Research Journal, https://saarj.com ISSN: 2249-7137 Vol. 11, Issue 3, March 2021, pp. 2533-2539 DOI: 10.5958/22497137.2021.00899.5

18. Mahfuza Rahimjanovna Shermatova "The Analysis of Examples of Classical Literature in the Primary School" Published in International Journal of Trend in Scientific Research and Development (ijtsrd), ISSN: 2456-6470, Special Issue | International Research Development and Scientific Excellence in Academic Life, March 2021, pp.137-140, URL: https://www.ijtsrd.com/papers/ijtsrd3877 4.pdf

19. Yusufjonova M. ABDULLA KAHHAR AS A SKILLFUL TRANSLATOR //European Journal of Research and Reflection in Educational Sciences Vol. - 2019. - T. 7. №. 12. M Yusufjonova - European Journal of Research and Reflection in ..., 2019 idpublications.org 
20. Shermatova M. R. BOSHLANG'ICH SINF O'QUVCHILARINI TEXNOLOGIYA FANIDA AMALIY ISHLAR ORQALI HAR TOMONLAMA TARBIYALASH //Интернаука. - 2019. - №. 1-2. - С. 58-59.

21. ШЕРМАТОВА М. Р. ТЕХНОЛОГИИ ДИСТАНЦИОННОГО ОБУЧЕНИЯ //ОБРАЗОВАНИЕ. НАУКА. КАРЬЕРА. 2019. - С. 93-95.

22. Шерматова М. Р. ТЕХНОЛОГИИ И ТРУД КАК ЧАСТИ ОБРАЗОВАТЕЛЬНОЙ КУльТУРЫ //Педагогика и психология в современном мире: теоретические и практические исследования. - 2018. - С. 101-104.

23. Шерматова М. Р. Особенности и методики применения информационнокоммуникативных технологий для активизации учебной деятельности в образовательном процессе на уроках в начальной школе //Молодой ученый. 2017. - №. 7. - С. 509-511.

24. ШЕРМАТОВА М. Р. ПРАКТИЧЕСКИЕ МЕТОДЫ И ПРИЕМЫ РЕАЛИЗАЦИИ ИКТ ДЛЯ АКТИВИЗАЦИИ УЧЕБНОЙ ДЕЯТЕЛЬНОСТИ МЛАДШИХ ШКОЛЬНИКОВ //МОЛОДЕЖЬ И СИСТЕМНАЯ МОДЕРНИЗАЦИЯ СТРАНЫ. - 2017. - C. 451-454.

25. Шерматова М. Р. Межличностные взаимоотношения в преподавании технологии //Молодой ученый. - 2017. №. 43. - С. 129-131. 